\title{
1MDB: The Financial Accounting's Question of Going Concern
}

\author{
Azham Md. Ali \\ Department of Accounting and Finance, Faculty of Management and Economics \\ Universiti Pendidikan Sultan Idris, 35900 Tanjong Malim Perak Malaysia \\ Tel: 015 48117771, Fax: 015 48117295, e-mail: azham@fpe.upsi.edu.my
}

Doi:10.5296/ jpag.v5i4.8884 URL: http://dx.doi.org/10.5296/ jpag.v5i4. 8884

\begin{abstract}
It was only in the second quarter of 2015 that the authorities had admitted that the 1Malaysia Development Berhad (1MDB) was a company experiencing financial distress. But it appeared that the company had began to suffer from insolvency as early as the last quarter of 2014 when it began to fail to make timely payments on both assets purchased and debts overdue. It also seemed that the company had succeeded in hiding its going concern question with the repeated acts of revaluation of some of its assets over the years. Without such revaluations, the company would have shown significant losses in its income statements for many years leading to the picture that it was in fact a company in financial distress.
\end{abstract}

Keywords: 1MDB, insolvency, assets revalution 


\section{Introduction}

By the end of 2014, a question might have arisen in many that the 1MDB was not quite a going concern. They might not be so far away from the truth for there were at least two signs that the 1MDB has been a company troubled by a lack of liquidity: the repeated revaluation of some of its assets and the failure to make the timely payments on both assets purchased and debts overdue. But, first, there is a need to figure out the amount of debts held by the company. Hence, the next section discloses just that to be followed with the discussion on the two signs of going concern issues faced by the company. Having discussed the signs of a company with serious going concern issues, the writing come to an end with the delineation of two important pieces of writing on the 1MDB's "unsustainable" entity position.

\section{What is the total amount of debts?}

It was in the middle of March 2015 that the Parliamentarians Pua and Rafizi mentioned that they had doubts on whether 1MDB could be rescued by the government's efforts as it sits on a RM42 billion debt (Anand, 2015a). But, on the very next day, Khairie Hisyam for the Kinibiz had instead mentioned that as of end-March, 2014 the 1MDB had racked up some RM 48.9 billion in liabilities (Khairie, 2015a).

Later, at the end of April 2015, during the Impian Sarawak fundraising dinner in Subang Jaya, the Democratic Action Party (DAP) secretary-general Lim Guan Eng mentioned figure the same as that coming from Pua and Rafizi above (Musliza, 2015). Specifically, Lim was reported to say that it was necessary for the people to know the truth about the nation's debt-ridden investment arm because Putrajaya had until now failed to reveal 1MDB's real debt situation. Notably, he was quoted to say: "They say they have debt of RM42 billion, then asset of RM52 billion which was enough to cover and pay the debt. How did they get RM52 billion? They only play with numbers. I am an accountant, I know. They only marked up the price. When selling the price does not reach the amount, that is why we said 1MDB is almost bankrupt."

Aside from the politicians, P. Gunasegaram who is also the founding editor of business news and views portal KiniBiz had raised at the end of April 2015 the matter of 1MDB's debts (Gunasegaram, 2015a). He did this as part of his background information of the company prior to his delineation of the ten things which he believed the company should be disclosing in order "... to soothe frazzled nerves and convince us Malaysians our money is safe." As he put it:

Next a quick look at its financials from its annual reports: assets of some RM51 billion, liabilities of RM48 billion, borrowings of RM42 billion (RM46 billion if we include some forms of payables which look like debt) as at March 31, 2014. If not for revaluation of properties - acquired cheaply from the government - by some RM4 billion over the years, it would not have made profits at all.

Finally, in December 2014, Khairie Hisyam his colleague at Kinibiz had disclosed (in a damaging response to deputy minister of finance Ahmad Maslan's remark that there was nothing worrying about the $1 \mathrm{MDB}$ ) that in FY14, the company had accumulated debts 
amounted to RM41.9 billion - an increase of 15.7\% from FY2013 (Khairie, 2014a). Notably, this amount was some billions ringgit lower than the amount he mentioned so many months earlier. Notably too was the very next thing he wrote following that remark: "The debt figure is worrying because $1 \mathrm{MDB}$ had proved to be facing difficulties in servicing its debt obligations, restructuring its RM5.5 billion bridging loan from Maybank Investment Bank in 2012 multiple times. This had in turn delayed the fund's proposed listing of its power assets."

\section{Was the 1MDB in financial distress?}

To hear it from the top management there was clearly no such thing. Note the following as reported by Kinibiz around the middle of November 2014 (Bernama, 2014):

1Malaysia Development Bhd (1MDB) has given an assurance that all its investments were prudent and professionally managed. "Some of the loans are long-term in nature but we believe this financial commitment can be met. We are also in the process of adding and unlocking value to the assets that we have acquired," 1MDB chairman Tan Sri Lodin Wok Kamaruddin told reporters today. Dispelling misconceptions about 1MDB's ability to repay loans, he said $1 \mathrm{MDB}$ was looking at restructuring its loans to address the mismatching long-term investment projects and short-term loans. He said its ventures in the Tun Razak Exchange (TRX) and Bandar Malaysia projects as well as in the energy sector were long-term in nature with long-term gestation periods.

Nonetheless, there were certainly two clear signs that the 1MDB was (and still is?) a company experiencing financial distress. One came in the form of repeated revaluations of the company's assets. It seems that without such revaluations there would instead be massive losses posted every year since it came into the picture as a company linked to the federal government of Malaysia. Aside from the repeated act of revaluations of assets, the company had also appeared to have experienced difficulty to pay its debts in late 2014. But, it was only six months later when a clear admission by the government of $1 \mathrm{MDB}$ experiencing financial distress came about.

Repeated revaluations of assets. It was in April 2014 that Stephanie Jacob of KiniBiz filed a report on the $1 \mathrm{MDB}$ 's financial statements which covered the accounting period ended on Mar 31, 2013 (Jacob, 2014). In it, she dwelt a little bit on the 1MDB's measurement of some of the group's assets and liabilities at fair value for the purpose of its financial reporting. Early on she mentioned that the 1MDB auditor Deloitte had pointed out the use of "market-observable data to the extent that it is available" by the 1MDB directors. If such data was not available, an independent professional qualified valuer engaged by the group would be brought in to come out with the estimations.

For the period under review, the third party valuer was $\mathrm{CH}$ Williams Talhar \& Wong Sdn. Bhd. which had brought up the value of 1MDB investment properties from RM1.78 billion at end March 2012 to RM6.18 billion at end March, 2013! Next she noted among others: "The land value grew mainly on the back of a revaluation of 1MDB land in the Tun Razak Exchange area and the Sungai Besi area to RM2.74 billion from RM569.9 million previously. 
This in turn contributed to the significant increase in profit recorded by the group as of end March 2013."

On the very same date that Stephanie filed that report of hers, a colleague of hers Khairie Hisyam filed quite an interesting report himself (Khairie, 2014b). Khairie started out with the following revelation: "State investment fund 1Malaysia Development Berhad (1MDB) saw RM1.85 billion in actual losses last year after taking away its paper profit of RM2.73 billion from property revaluation."

Next, he pointed out:

According to 1MDB's 2013 annual report, it recorded RM878 million in pre-tax profits for the financial year ended March 2013. But this figure took into account fair value gains of RM2.73 billion which came from revaluing the fund's investment properties essentially paper gains. Overall, 1MDB's investment properties for FY13 stood at RM6.18 billion, an increase of more than threefold compared to RM1.78 billion held in FY12.

And, the reason for having such paper gains was pretty kosher. As he put it:

According to the annual report, the land held for the Bandar Malaysia and TRX projects were classified as investment properties in accordance to the Malaysian Financial Reporting Standards (MFRS), which 1MDB adopted for FY13 in lieu of the previous Financial Reporting Standards (FRS). The classification was made because the blueprints for both developments had not been finalised.

To be more exact:

MFRS stipulates that fair value gains from investment properties are to be recognised in profit and loss, implying that the RM2.73 billion in revaluation gains were only recognised in 1MDB's profit and loss statement because the fund had not finalised the blueprints for both projects. Once finalised these land plots would no longer be included in 1MDB's investment properties, meaning any further gains from revaluation would no longer be recognised as profit.

Within a couple of days of these reports appearing in the KiniBiz, another report by P. Gunasegaram came out. He had certainly not minced his words in describing the debilitating state of the 1MDB's financial situation (Gunasegaram, 2013). He wrote early on: "Meantime up to Mar 31, 2012 1MDB was basically a company devoid of any businesses and had lots of loans which it effectively on-lent to others. It had no significant income-generating businesses, but continued to show a profit only because of revaluation of property which it had obtained cheaply from the government."

Later, he detailed out what could be discerned from the financial statements:

The accounts does not paint a pretty picture... For the year ended Mar 31, 2012, 1MDB made group a pre-tax profit of RM44.7 million, which was already sharply down by more than 90 percent from the RM544.3 million it made in the previous corresponding 
year. But if not for a gain on revaluation of investment properties of RM570 million, it would have made a loss of RM525.3 million...

Apparently that amount of loss was close to 100 percent more in comparison to the loss amount that would have been incurred the year before assuming there was no revaluation of certain assets done for that year. Noted P. Gunasegaram: "For the previous year, it made a revaluation gain on property of RM827.6 million without which it would have declared a loss of RM283.3 million. If we strip out the property revaluation gains, 1MDB made a pre-tax loss of RM525.3 million for the year to Mar 31, 2012, deepening its losses by RM242 million." He next concluded by saying: "It seems like the main reason that $1 \mathrm{MDB}$ is revaluing its property assets is to show that it is making a profit."

As if this was not bad enough, his analysis of the financial statements ended March 31, 2012 had led him to the following conclusion:

On the other side of the balance sheet, total liabilities amounted to RM8.38 billion, out of which RM7.82 billion were loans and borrowings. Equity was rather token because paid-up capital was a just RM1 million and accumulated equity it has mainly reflected revaluation surpluses from earlier revaluations of property. Total equity or shareholders' funds as at Mar 2012 amounted to RM\$1.16 billion. In the last two years alone, gains that it made on revaluation of property amounted to RM1.4 billion, clearly indicating that most if not all of the equity accumulation came from this.

Just before the year 2014 finally came to an end, another four quite revealing pieces of writing related to the $1 \mathrm{MDB}$ 's revaluation tactics emerged. The first two described next came out in the month of November while the next two in December.

The first from The Malaysian Insider mentioned that the secretary general of Parti Keadilan Rakyat (PKR) Rafizi Ramli had claimed that there was an attempt to hide the real losses incurred by $1 \mathrm{MDB}$ through the method of revaluating the company's assets (Diyana, 2014). He was quoted to say: "Bagi tahun 2013, harta-harta dinilai semula mencatatkan peningkatan sebanyak RM2.74 bilion... Dan bagi tahun 2014 nilaian semula harta dan aset 1MDB berjumlah RM897 juta." (For the year 2013, the revaluated assets had showed an increment of RM2.74 billion... And for the year 2014 the revaluated assets had totaled to RM897 million.) He next claimed that if not for the assets revaluation, there would be losses for RM1.96 billion for 2013 and RM1.56 billion for 2014.

As for the second piece, it was none other the DAP national publicity secretary and member of parliament for Petaling Jaya Utara Tony Pua, in response to the remark made by the deputy finance minister Ahmad Maslan that the $1 \mathrm{MDB}$ would return to profitability in financial year 2015, who wrote (Pua, 2014):

Since 2011, 1MDB has achieved profitability entirely as a result of revaluation of properties which were sold to $1 \mathrm{MDB}$ by the federal government at heavily discounted prices. In 2011, 1MDB made a profit of RM544 million on the back of a property revaluation of RM827 million. In 2012 and 2013, 1MDB continued to make profits of RM45 million and RM778 million on the back of RM570 million and RM2,736 million 
in property revaluation respectively. For the most recent financial year, 1MDB made a loss of RM665 million despite a revaluation of RM897 million.

Next, he summarized that from 2011 to 2014, while the company had reported cumulative net profit of RM690 million, the truth was that it would have shown a huge cumulative loss of RM4.33 billion - if there were no paper gains arising from the revaluation of properties that it bought from the government at extremely low prices! And, for the year 2014 in particular, Pua had pointed out that in case there was no property revaluation taking place the company would have shown a loss of RM1.61 billion instead of that of RM665 million!

In the following month of December, it was again Pua who came out with the crystal clear remarks on 1MDB's assets revaluation practices as an escape route for the company to avoid showing losses in its income statements ("Ask 1MDB to", 2014). Specifically, he was reported to have said that there existed many reports stating out that the company had only made profits consecutively from 2010 to 2013 due the revaluation of properties and other assets, and not because of any tangible operating profit. And, when it concerned the properties in particular, these were in fact acquired at rock-bottom prices from the federal government.

Next, he was said to say that in 2010 the 1MDB had made a "profit" of RM424 million on the back of a revaluation of its unlisted shares in a joint-venture investment of RM600 million. And, in the next three years, the 1MDB recorded paper profits had ranged from RM544 million to RM778 million on the back of its revaluation of properties of RM827 million, RM570 million and RM2.7 billion in 2011, 2012 and 2013, respectively.

Hence, if not for the asset and property revaluations, as Pua had pointed out, the 1MDB would have made consecutive losses of RM236 million, RM273 million, RM526 million and RM1.9 billion from 2010 to 2013. Pua also said that despite recording a property revaluation of RM897 million the 1MDB had reported losses of RM665 million in 2014. All in all, as he was reported to say, over the five year period, the company which had incurred debts to the amount of RM42 billion to date had also incurred a staggering cumulative loss of RM4.56 billion.

Finally, for the fourth hard hitting piece that came out in KiniBiz in December 2014, the writer Khairie Hisyam disagreed with the remark made by the deputy finance minister Ahmad Maslan that there was nothing to worry as far as the $1 \mathrm{MDB}$ was concerned. He wrote (Khairie, 2014a):

Those tracking controversial state investment fund 1Malaysia Development Bhd (1MDB) would, by now, be aware that there are pressing issues over how the fund is managed as evidenced by its accounts. But not deputy finance minister Ahmad Maslan... But here's the issue with the deputy minister's statement: there are real problems at $1 \mathrm{MDB}$ and they are not, by any measure, simple perception.

And, one of the reasons for his disagreement was concerned with the matter of assets revaluation: 
On the face of it, yes, 1MDB had posted profit for four consecutive years before sinking Into red for the latest financial year ended March 2014 (FY14) on the weight of higher borrowing costs. However, here's a couple of questions for Ahmad Maslan: What sort of profit were there in the four financial years spanning FY09-FY13 - paper profit or real profit? Would there had been 'profit' at all had paper gains from annual property revaluation, an unusually high frequency of assets revaluation at that, not offset real losses year after year? Bear in mind that these come from 1MDB's own accounts filed to the Companies Commission of Malaysia (CCM). In other words, the information does not get any more correct than that. Paper gains aside, continuously posting real losses year after year would rank as a big issue at any company, let alone a state investment fund such as 1MDB.

Difficulty in making the necessary debt payments. After behaving for some time that the $1 \mathrm{MDB}$ was doing well even when numerous personalities from outside the government had said otherwise, a federal government minister had finally came out in mid April 2015 with the remark that the $1 \mathrm{MDB}$ was experiencing cash flow problems (Mohd-Izwan, 2015). The minister in the prime minister's department Datuk Seri Abdul Wahid Omar was reported to say that the $1 \mathrm{MDB}$ was a burden as a result of its failure to generate cash flow against its huge debts. He was also said to say that the company had taken loans from banks and the capital market to purchase assets - but failed to raise cash flow, causing it to be "unsustainable". To improve the situation the government had decided on three strategic steps which included the halting of new borrowings except to service or refinance current debts.

But, it seems that such admission should have been made at the very least six months earlier, for it was in the first half of November that Tony Pua revealed that the 1MDB had just missed the third deadline to pay up for a RM317.3 million land from Tadmax Resources Bhd (Zachariah, 2014). He was quoted to say: "After paying the $10 \%$ deposit for the land in February this year, 1MDB had been unable to make payment for the balance of the transaction despite shifting the deadline from August 20 to September 30 to October 10 and then to October 31." He then concluded that this was a sign that the 1 MDB was financially stretched.

In the very same news report, Pua had also made another startling disclosure: the company was forced to extend, restructure and refinance RM6.17 billion of debt twice in the past year. Pua claimed that this was revealed in 1MDB's financial statements for March 2014 submitted to the Companies Commission in the previous week. Specifically, according to the financial statements, 1MDB had to extend the RM6.17 billion loan for six months when it was due for payment on November 22, 2013, and had only managed to pay RM670 million when it was due again in May 2014. Pua had also revealed that the 1MDB had to refinance the loan via a RM5.5 billion term loan facility and that the Singapore's Business Times had reported that the debt of the sovereign wealth fund had come at an expensive price of $2.5 \%$ in interest above the annual cost of funds. This was in addition to the RM20 million to RM30 million in upfront fees. Pua had thus surmised: "The struggle $1 \mathrm{MDB}$ is facing in repaying its loan, as 
well as the price the company agreed to reschedule the loan, certainly provides clear evidence that the company is facing financial difficulties in balancing its cash flow."

A week after exposing the failure of the $1 \mathrm{MDB}$ to make the timely payments, Pua came out with the claim that the company was facing difficulties in balancing its cash flow to the point that it had diverted part of the proceeds of the US\$3 billion (RM9.6 billion) loan raised by its subsidiary to fund operating expenses and pay off its burgeoning debts ( $\mathrm{Ng}, 2014)$. What happened was that in March 2013 the company's wholly owned subsidiary, 1MDB Global Investments Limited, had issued a bond to raise US\$3 billion. In the offering circular issued by Goldman Sachs, the 1MDB Global Investments Limited will "either on-lend all of the nett proceedings of this offering" to Abu Dhabi Malaysia Investment Company (ADMIC) or "use the nett proceeds of the offering to fund its investments in ADMIC".

However, in the financial statements for the year ended March 2014, 1MDB had said that the remaining nett proceeds that amounted to US\$1.16 billion was diverted to parent company 1MDB to repay debts and fund its operating expenses. Said Pua: "The transfer of US\$1.16 billion, or $42.7 \%$, of the funds to be used by the parent company, 1MDB, to help pay its debt and cover the shortfall in operating expenses is a clear breach of the offering circular."

Later in the following month of December, in reacting to remark made by the deputy finance minister Datuk Ahmad Maslan that the 1MDB did not have any issue whatsoever, Pua had challenged him to make the recommendation to both the Public Accounts Committee (PAC) and the auditor general to probe the company ("Ask 1MDB to", 2014). He had also pointed out that the company was only able to show profits in its income statements consecutively from 2010 to 2013 due to revaluation of assets and properties, and not because of any tangible operating profit!

Next, he claimed that the deputy minister was off the mark when he attempted to assure Parliament last month that the fund was in good financial health by saying that it never missed a repayment deadline. This was because late in the previous month, the company had failed to settle debt amounted to RM2 billion - and that was not the first time such had happened since the debt was part of the amount due in November the year before! And just like before, the 1MDB had asked for a further extension from the financiers. Pua's damaging response ended with the remark that the $1 \mathrm{MDB}$ that the deputy minister had declared to be in the clear was in fact practically insolvent. Hence, without the injection of new funds, it was unable to execute its multi-billion projects.

As for which debt of the 1MDB that Pua was referring to above, note the following that Khairie Hisyam of KiniBiz had disclosed on the very same day that Pua made the interesting disclosure (Khairie, 2014a): "The debt figure [of RM41.9 billion in FY14] is worrying because $1 \mathrm{MDB}$ had proved to be facing difficulties in servicing its debt obligations, restructuring its RM5.5 billion bridging loan from Maybank Investment Bank in 2012 multiple times."

Also, in the very same month of December, the Malaysiakini reported that the veteran newsman A. Kadir Jasin had revealed in a blog posting that the 1MDB had sought from the 
Central Bank an extension period from three to six months for its non-performing loans (NPL) ("'1MDB got loan", 2014). As stated in the same news report the non-performing loans are defined as loans which are in default or are close to being in default. Kadir disclosed that the Bank Negara governor Zeti Aktar Aziz was unhappy with 1MDB's large borrowings - but she had to agree to the request for failing to do so could seriously impact the banking system! Stated Kadir: "If it (the extension) was not given, there would have been a massive default and Tier 1 banks that extended the loans would have to make huge provisions. This could lead to the downgrading of the local banking system." Kadir had also revealed that some "very harsh words" were traded during the meeting between 1MDB top officials and Bank Negara to the point that the $1 \mathrm{MDB}$ chairperson Lodin Wok Kamaruddin had offered to step down.

Come February 2015, there was a flurry of news on the 1MDB's inability to pay its RM2 billion debt mentioned earlier. Early in the month, the Malaysiakini reported that on January 30, Reuters had revealed that the tycoon Ananda Krishnan will lend RM2 billion to the company to settle a loan to Malayan Banking Bhd (Maybank) and RHB Capital Bhd ("Come clean on", 2015). In the very same news report, there was also a disclosure of the matter mentioned in the previous paragraph coming from the veteran newsman Kadir. This time however the information came not from Kadir but instead it was from the newspaper the Edge Financial Daily which said that the Central Bank Negara had summoned the key executives of $1 \mathrm{MDB}$ over the debt repayment issue and warned them of dire consequences, should they fail to meet the next deadline at the end of January. Finally, in the same news report remarks coming from Tony Pua and Tun Dr. Mahathir were quoted upon.

In regard to the former, he had mentioned that 1MDB's repayment of the loan was a matter of "irrefutable public interest" that demanded prompt answers from either 1MDB or the Finance Ministry. He was also reported to have pointed out that the finance and prime minister Najib could not afford to remain silent on that very matter without further eroding the confidence of the financial markets. He next made the call for the Auditor-General to engage a "reputable independent auditor to uncover its financial shenanigans". As for the quoted remark coming from Tun Dr. Mahathir, it came in the form of question:

"Why is there a need to borrow money to pay debts when you have RM8 billion (in the Caymans Island account)?"

A couple of days after Tun Dr. Mahathir had said so, Tony Pua in an article filed by the same news portal Malaysiakini had mentioned that Singapore's Business Times had reported that the 1MDB CEO Arul Kanda Kandasamy would not repatriate the US\$1.1 billion (RM3.9 billion) recently "redeemed" from the Cayman Island investments (Pua, 2015). The reason was that "the money will be used to service the firm's debt interest payments". CEO Arul was quoted to say: "There's a very sensible and simple reason for that. We are keeping the money in US dollars as we have US\$6.5 billion (RM23.06 billion) in bonds out there, in which interest payments come up to nearly US $\$ 400$ million (RM1.4 billion) a year." This had in turn led Pua to come out with the following response: 
The excuse given by Arul Kanda must have completely puzzled and tickled the readers of Singapore Business Times out there. 1MDB has a RM2 billion loan due to be repaid on the January 31, 2015. This loan was originally to be paid in November 2014, before being rescheduled twice. This RM2 billion loan itself is part of a rescheduled and restructured debt it couldn't pay in November 2013. 1MDB is clearly struggling to raise the necessary funds to repay the above loan to Maybank Bhd and RHB Bank Bhd. Despite that, the newly appointed CEO can actually tell the investment public with a straight face that they are reserving the RM3.9 billion "cash" they have overseas for "future" interest payments of their other debts.

Next, he raised a very interesting point:

What Arul Kanda is telling us is that he would rather set aside the RM3.9 billion alleged "cash" overseas to pay for interest payments amounting to US\$400 million (RM1.4 billion) a year due some time in the future despite the fact that 1MDB has a RM2 billion loan which is already overdue. Does he actually expect Malaysians out there to naively believe him?

Notably in the next three paragraphs of his article, Pua had raised some very interesting questions that in the final analysis provided the picture that the 1MDB was most probably devoid of cash needed to repay its debts - even when the various personalities closely connected to the company and its yearly financial statements had made repeated disclosures that it possessed billions of cash or cash equivalents. Hence, it is not surprising to find that at the end he had mentioned the following: "I continue to reiterate my earlier call for Prime Minister Najib Razak to instruct a special audit of $1 \mathrm{MDB}$ by the auditor-general or a reputable independent auditor to uncover its financial shenanigans." Perhaps it is worth noting that such suggestion that appeared as the very last paragraph of his article was preceded by the following warning:

At stake here is the stability and credibility of the entire Malaysian financial system. If $1 \mathrm{MDB}$ defaults on the RM2 billion loan, then the entire outstanding debt of $1 \mathrm{MDB}$ becomes due. Under such circumstances, the Malaysian financial system may collapse under enormous stress while the government's credit ratings is bound to take a massive hit.

Believe it or not, following the publication of this writing by Pua by Malaysiakini in the first half of February 2015, the depressing saga of RM2 billion debt repayment of 1MDB went on and on for some months after. Check out the followings:

For the rest of the month of February, three quite interesting news report were published. In the news portal Free Malaysia Today, it was mentioned that tycoon T. Ananda Krishnan had come to the rescue of beleaguered $1 \mathrm{MDB}$ at the eleventh hour to ease its immediate financial worries (FMT Reporters, 2015a). As noted Free Malaysia Today: "Banking sources say that the repayment was made late yesterday, presumably after terms of the bailout were finally agreed between $1 \mathrm{MDB}$ and Ananda's own investment arm, Usaha Tegas Sdn Bhd." Notably, in the latter part of the very same report, the following interesting bit appeared: 
$1 \mathrm{MDB}$ has come under fire in recent months for its mammoth debt, which industry sources say is in excess of RM42 billion. Chief among its critics are former Prime Minister Tun Dr Mahathir Mohamed. Dr Mahathir has repeatedly asked how 1MDB benefits Malaysians... In mid-January this year, Mahathir had questioned the current whereabouts of funds to the tune of US $\$ 2.318$ billion (RM8.24 billion) which was said to have been invested in the Cayman Islands, and which 1MDB's CEO Arul Kanda Kandasamy said had been redeemed. Yesterday, FMT reported the former Prime Minister as suggesting that Najib quit as Prime Minister if he could not perform.

In the very same day that the Free Malaysia Today piece above came out, KiniBiz had also filed a report where the following was mentioned (Sharmila, 2015):

It's all over the news that billionaire Ananda Krishnan has bailed out 1Malaysia Development Bhd (1MDB) so that it wouldn't default on its RM2 billion loan... What's strange is that $1 \mathrm{MDB}$ is remaining silent on the subject, neither confirming or denying the bailout... If true (and at this juncture, it probably is), this latest exploit of 1MDB raises more questions than answers, a habit the firm continues to impose on the public...

Next, in trying to get to the truth, G. Sharmila who filed the KiniBiz report had disclosed that the following questions were sent to $1 \mathrm{MDB}$ :

- Can $1 \mathrm{MDB}$ confirm or deny that $1 \mathrm{MDB}$ must meet its loan obligations for RM2 billion taken out in May 2014 by Feb 18 or face default?

- Can 1MDB confirm or deny that businessman Ananda Krishnan is helping 1MDB meet that loan obligation?

And the (email) reply from $1 \mathrm{MDB}$ had the following content:

I'm afraid that, as I have said in the past, the matter you refer to relates to a private agreement between $1 M D B$ and its banking partners. Any such agreement is bound by confidentiality clauses and, as such, we are unable to comment specifically on this matter.

On background, however, I can say that I have been various publications provide different dates for this alleged deadline - WSJ (Wall Street Journal) says end of the month, MI (Malaysian Insider) says 18 February. So clearly someone's sources are wrong. For me, that should raise some questions about the reporting. (Emphasis already around.)

With such reply, G. Sharmila had stated out next that since there was no outright denial of AK's involvement in the repayment of the loan she would now assume the tycoon's participation in the deal. Just a few days later, however, a colleague of hers, Khairul Khalid, had filed a report saying something else (Khairul, 2015).

Early on, Khairul mentioned that within the previous two weeks the Malaysian government had raised funds by issuing two series of Malaysian Treasury Bills (MTB) or short term debts amounting to RM2.1 billion. The MP Rafizi Ramli who was credited with the revelation was 
also quoted to say: "It is an extraordinary amount and is almost the same as 1MDB's debts that were settled last week. It looks like it wasn't the banks or Ananda Krishnan that rescued 1MDB. It was the Malaysian government." Rafizi who had gathered the information from the Central Bank's website was also quoted to say:

It would seem that quietly and without the knowledge of the public, the Malaysian government has bailed out $1 \mathrm{MDB}$. It is extremely dangerous. If we allow manipulations of government cashflow to pay unknown debts, we don't know how far the government can go. This has to stop... These treasury bills are usually used to raise funds for short term cash flow. Larger amounts required by the government are normally obtained by issuing long term bonds, which are usually justified by invesment in specific projects.

Next, Khairul mentioned that what happened as far as Rafizi was concerned was this: the IMDB's much publicised negotiations with Ananda Krishnan to settle the RM2 billion debts was probably aborted - “... due to uncertainties surrounding 1MDB's involvement in the RM11 billion Jimah East power plant project, which in turn may affect 1MDB's proposed IPO (initial public offering)." Khairul had then ended his piece with the remark coming from Rafizi for the 1MDB to explain how they settled the RM2 billion debt and if there were any government funds involved. But, as the next month of March came and went away, there was no clarity to be found.

In late March, Ram Anand of the Kinibiz reported that the Finance Ministry had written in a parliamentary reply on March 14 that the allegation that Ananda Krishna had lent money to the $1 \mathrm{MDB}$ was not true (Malaysiakini, 2015). And, what was true instead was revealed in late March by the second finance minister Ahmad Husni Hanadzlah who told the Dewan Rakyat that Ananda Krishnan's Tanjong Public Ltd firm had helped secure RM2 billion in "refinancing" for 1Malaysia Development Bhd (1MDB) via private investors. The minister was quoted to have said: "Refinancing is normal in the corporate sector, only that this refinancing was not from a bank. It was from private investors, and was managed by Tanjong." He was also reported to say that the refinancing exercise is to be settled over 15 months for the principal amount, while the interest for over six months. As for the money coming from Cayman Islands, he pointed out that the 1MDB had opted for it to stay in Singapore because it intended to use the money to service loans in US dollars.

It is noticeable that in a news report filed by the Free Malaysia Today, there was a couple of additional but intriguing remarks mentioned (FMT Reporters, 2015b). The first was concerned with the contents of the parliamentary reply dated March 14 - not only that Ananda Krishna as stated above was not the one paying the RM2 billion debts (in contrast to the report filed the day before by The Malaysian Insider that 1MDB had settled the loan with intervention from Ananda), but also that the fund used to pay the debts came from the 1MDB's own Cayman Island funds!

As for the other intriguing remark, it was concerned with the Cayman Island funds of the company. Specifically, it was stated out in the news report that the finance ministry's written reply dated March 14 had disclosed that the 1MDB had withdrawn its US\$2.318 billion (RM8.5 billion) offshore savings in the Cayman Islands in two tranches, and had used the 
first tranche to pay back "loan interest, working capital and other scheduled commitments". This tranche was US $\$ 1.215$ billion (RM4.46 billion), while the second tranche of US $\$ 1.103$ billion (RM4.05 billion) was still kept in foreign currency at BSI Bank Limited Singapore to be used to repay loans in foreign currency that were due this year.

Therefore, with the news that came out the day before that 1MDB's RM2 billion debts had been settled by private investors through assistance coming from Ananda Krishnan's firm Tanjong, Ram Anand in another news report filed at the end of March in Malaysiakini (to be more exact on the very next day after the news report he filed with the KiniBiz mentioned earlier) had reported that the PKR had threatened to refer second finance minister Husni Hanadzlah to the parliamentary rights and privileges committee for contradictory answers from the government on Ananda Krishnan's involvement (Anand, 2015b). As stated in the news report early on:

Yesterday, Husni told the Dewan Rakyat that Ananda Krishnan's firm helped secure a RM2 billion refinancing loan for $1 \mathrm{MDB}$ from private investors. This is in direct contradiction to a previous parliamentary written answer that Ananda Krishnan did not loan any money to $1 \mathrm{MDB}$ and that it would be using the $1 \mathrm{MDB}$ funds repatriated from the Cayman Islands to service the bank interest payments on its debts.

To be more specific, it was the Bayan Baru MP Sim Tze Tzin from the PKR who was mentioned to have demanded the finance ministry to explain the truth regarding the debt payment or else his party would refer Husni to the rights committee for misleading the House. It is also notable that the same MP had in fact raised the issue of whether the loan was given according to Bank Negara Malaysia (BNM) regulations. He was quoted to say: "Normally, only a bank can give a loan. Who are these private investors that had given the loan? Were the rules relaxed for these investors?"

It is notable that it was not just MP Sim from the PKR who had raised the matter of contradiction of remarks coming from the side of the government (or its associates) on the RM2 billion debt payment, for the personality Khairuddin Abu Hassan from the governing party UMNO itself too had raised the same matter. In a press statement which he issued at the end of March, he was reported to say that the 1MDB's CEO Arul Kanda Kandasamy had been exposed as a liar in a disclosure made by second finance minister Ahmad Husni Hanadzlah about the source of funds that enabled 1MDB to settle a RM2.1 billion debt with Maybank and RHB Capital (FMT Reporters, 2015c).

To be more specific, the fact that Husni had told Parliament the day before that Tanjong PLC owned by billionaire $\mathrm{T}$ Ananda Krishnan had arranged the funding with the help of private investors contradicted the dismissal made by Arul in the previous month of February talk that the loan was settled with Ananda's help. In the same press statement, Khairuddin demanded that Arul make a public statement explaining why he was "prepared to lie and mislead the public" about the funding source for the loan settlement. He also urged the police and Malaysian Anti-Corruption Commission (MACC) to act firmly against Arul and had them reminded that Arul was a public servant by virtue of his positions in a company that is wholly owned by the Finance Ministry. When it concerns the MACC head Abu Kassim 
Mohamed in particular Khairuddin raised the need for him to "open his eyes widely" to see Arul as a liar!

Finally, it should be worth pointing out that within the first half of March 2015, when there was not much news coming out in regard to the matter of RM2 billion debt payment in comparison to what took place later in the month as noted above, a report appearing in the Singapore Business Time had mentioned that the Malaysian government had extended a nearly RM1 billion (S\$373 million) loan to 1MDB (Gabriel, 2015). Note the following which appears early on in the news report:

The Business Times understands that the loan was provided by the Ministry of Finance, $1 M D B$ 's shareholder, to deal with the firm's cash flow woes as it is saddled with huge interest payments. The firm has racked up debts of some RM42 billion with worries of a potential default weighing on Malaysia's sovereign rating and currency. When contacted, a spokesman of 1MDB declined comment. The loan of some RM970 million, according to a source, was disbursed following a cabinet meeting a fortnight ago to deliberate and decide on a cash injection plan for $1 \mathrm{MDB}$. It is understood that the Malaysian cabinet had set certain conditions for $1 \mathrm{MDB}$ before the funds were disbursed.

Within a few days after the news report had come out, in mid March, the national news agency the Bernama had filed a report which contained the remark made by the second finance minister Ahmad Husni Hanadzlah that the 1MDB had utilised RM600 million of the RM950 million allocated by the government as temporary available credit - prior to the company launched an IPO (FMT Reporters, 2015d). He was also quoted to say: "We provided the funds because we don't want the company to continuously be in debt. The debt will not only increase the amount to be paid but also include the interest rate. So, after the launching of the IPO and several other measures, we want to see the company review its financial structure to reduce their debt repayment burden."

In addition, he was reported to say that the cash flow problem faced currently by the company would be resolved by the end of 2015 through measures such as the rationalization of land owned by the company and the launching of IPO around mid year. Noticeably, he had pointed out that the $1 \mathrm{MDB}$ was facing the cash flow problem not due to management problems or misappropriation as had been alleged. In addition, he was quoted to say: "1MDB is involved in long-term investment, so to reap profit from the investments made would take some time. The company's financial statement for the year ended March 31, 2013 had shown profits but it only recorded a loss in 2014."

With this kind of stance coming from the government side, it is not surprising to find that there were parties around who disagreed. In fact, on the very next day after Husni's remarks above were reported widely upon by the various news portal and news agencies in the country, Pua took issue with what he considered to be Husni downplaying the 1MDB's cash flow problems and had accused him of being dishonest when responding to crucial questions as to how the company came into so much debt (FMT Reporters, 2015e).

And, when it concerns Husni's remark that 1MDB's cash flows issue would be resolved by 
year end in particular, Pua mentioned that based on the company's current financial status, it would take at the very least a RM5 billion injection by the government over and above the possible initial public offering of its energy division in order to get the company back on its feet again. And even such injection would provide mere temporary respite due to the fact that come 2016, after selling off some $80 \%$ of its only profitable division in the IPO, 1MDB would have no income generating assets to service or repay its massive outstanding debt!

Also note the following reaction to the remarks made by Husni above coming from DAP secretary-general Lim Guan Eng who is also Penang chief minister and Bagan MP ("1MDB will haunt", 2015):

Clearly, Ahmad forgets basic high-school accounting that bankruptcy is most commonly caused by insolvency in not having enough cash to pay your debts, even when your financial accounts show healthy accounting profits. There are many companies that have gone bust because they are unable to meet their short-term cash obligations despite having billions of dollars in assets. For Ahmad to admit 1MDB to be unable to pay its short-term cash obligations is to concede that $1 \mathrm{MDB}$ would go bankrupt without the RM950 million standby credit provided by the BN federal government. Without this standby credit, $1 \mathrm{MDB}$ would be unable to pay its short-term cash obligations, become insolvent and hence bankrupt.

At any rate, exactly a month after the second finance minister Husni mentioned the various controversial remarks of his as mentioned above, and as noted at the beginning of this very sub section of the paper, in mid April 2015 a minister in the prime minister's department Datuk Seri Abdul Wahid Omar had made the clear cut admission that the 1MDB was "unsustainable" as a result of its failure to generate cash flow against its huge debts (Mohd-Izwan, 2015). And, as noted above, such admission should have been made as early as the last quarter of the previous year.

\section{Why was not minister Wahid's admission of 1MDB being an "unsustainable" entity unsurprising?}

Within the previous one week plus prior to minister Wahid's admission of 1MDB being unsustainable, there were two pieces of quite revealing writings by Khairie Hisyam appearing in KiniBiz on 1MDB. Also, it is notable that a couple of days after minister Husni coming out with his various controversial remarks noted earlier, and several weeks prior to the publication of the two KiniBiz articles, a person under the name A.H. Manaf had written a piece on $1 \mathrm{MDB}$ being in financial distress. All in all these three writings appear to have encapsulated well the dire financial situation of the 1MDB with the arrival of the second quarter of 2015.

In the case of the first of the KiniBiz article that came out in April 4, 2015 by Khairie Hisyam, his introduction was quite telling (Khairie, 2015b): "Something hasn't been right at controversial 1Malaysia Development Bhd for a long time and the air now smells of desperation." Next, he mentioned that the people were now wondering as to whether the situation faced by the company was so terrible due to the fact that the federal government in 
recent days had produced "a myriad of decision changes and contradictory statements, as well as flip-flopping".

In regard to the issue of the $1 \mathrm{MDB}$ in financial crunch, note the following remarks of his appearing in the early part of his writing:

The issue is cash - despite billions of free cash stated in its accounts, the self-styled strategic development company had been desperately scrounging around for some to pay loans due. And a lot of different entities are providing cash to 1MDB too... These figures suggest 1MDB should have so much cash it shouldn't know what to do with it. Then why is the company in such dire straits of illiquidity?

Next, Khairie made the call that it was now time for full disclosure of the 1MDB's affairs. He wrote: "Malaysians should be informed of exactly what borrowings 1MDB has, from whom and due when. Tell us the repayment terms and exactly what assets and investments 1MDB has to show for its RM46 billions. Explain why 1MDB doesn't seem to have enough in its pockets despite indications otherwise from its accounts." And the reason of such disclosures as far as he was concerned was simply that the $1 \mathrm{MDB}$ was owned by the ministry of finance and which by extension would make all Malaysians to have an interest in its affairs.

About a week following the publication of the KiniBiz article that contains those sensible remarks, Khairie Hisyam had come out with another penetrating piece of writing (Khairie, 2015c). This time around he devoted a large part of his writing on what would have taken place assuming the 1MDB was a public-listed company on Bursa Malaysia instead of a fully owned government linked company. Related to this he mentioned early on: "Imagine for a moment that $1 \mathrm{MDB}$ is a public-listed company on Bursa Malaysia. Would the issues have dragged on for so long? Unlikely. 1MDB would not have been allowed its years of elegant silence, nor would its strange financial management go on for so many years."

Next, Khairie dwelt on a handful of issues of (mis)governance including "a strangely hasty" joint venture with PetroSaudi International Ltd in 2009, borrowing money at high rates while investing in lower return investments and seemingly having influential hand of businessman Jho Low in 1MDB's early dealings. And when it concerns the issue of financial crunch in recent time, Khairie mentioned that the $1 \mathrm{MDB}$ had billions in cash and bank balances in its annual accounts, and yet had to rely on businessman Ananda Krishnan and various other parties for some cash so that it could meet outstanding loan obligations earlier in the year! In this regard, he had succinctly noted:

Any public-listed companies worth its listing status would have seen the board of directors and senior management slaughtered over such questionable investment moves and mysterious lack of liquidity at its general meeting by shareholders. But not 1MDB. In fact Bursa Malaysia may have issued queries on these matters. By regulation such queries demand a proper response from the company within one working day - there would have been no way that $1 \mathrm{MDB}$ would be allowed to keep its silence for all these years had it been publicly listed. 
Finally, when it concerns the writing by A.H. Manaf published in The Malaysian Insider on March 17, 2015, there could not perhaps be a better one in the realm of 1MDB's quagmire to that day ("1MDB in financial", 2015). It is notable that for more than half of the contents of the paper was comprised of the various signs of financial distress faced by the company with the rest revolving upon the forensic audit which he claimed needed to be done to the company.

In regard to the $1 \mathrm{MDB}$ experiencing the financial distress, he made that very observation after delineating six separate events taking place since late 2014. These were: the taking up of US1billion loan in October 2014 bringing in additional RM3.7 billion to the existing debt amount of RM42 billion as at March 2014; the repayment of an existing RM2 billion bridging loan postponed from November 2014 to December 2014 and finally to January 2015 leading to confusing statements issued as to the source of the loan repayment; the government providing a "standby credit" of RM950 million of which more than two-thirds were drawn in the short duration of two weeks following the granting of the credit; the second finance minister Husni describing the company's finances and "gearing ratio" as "unsustainable" necessitating "an exercise to rationalise and consolidate its assets"; the news reports revealing that $1 \mathrm{MDB}$ was unable to proceed with the $3 \mathrm{~B}$ power project; and finally, the sudden resignation of $1 \mathrm{MDBs}$ CEO whose replacement, Arul Kanda, announced stark changes in business direction under the guise of "strategic financial review" involving the sale of assets, including "land assets which may be sold outright or partly sold through joint ventures". All in all, he said: "All of the above point to a clear picture - what we are witnessing here is a company in acute 'financial distress' suffering from unsustainable levels of 'corporate debt overhang",.

A.H. Manaf had defined the former as the company's inability to meets its financial obligation in a timely manner. And, in the case of $1 \mathrm{MDB}$, he pointed out that it appears that it was only able to meet its minimum obligations with assistance coming from either government-funded emergency loans or funds extended by a third party. He also mentioned that the reported problems with the $3 \mathrm{~B}$ project were classic symptoms of a company in financial distress for it was facing a situation of having to reject lucrative investment proposals due to its extensive debt levels rendered it unable to raise additional funding while a substantial proportion of its current revenues and cash flow goes to servicing existing debt.

When it concerns the "corporate debt overhang", he claimed that often it would lead to a "vicious downward spiral". In 1MDB's particular case, he claimed that the loss of 3B had serious repercussions on its short-term financial position, too, because its debt reduction proposal was based on the IPO of its energy subsidiary Edra. He had also pointed out that other symptoms of "corporate debt overhang" included excessive cost of borrowings which was depicted well in the case of the 1MDB with the notes to 1MDB's FY14 accounts detailing interest on borrowings (p. 122) show this to be the case.

He concluded next that he had to disagree with the second finance minister's contention that the recent emergency government loan to $1 \mathrm{MDB}$ "does not in any way constitute a bailout" because bailouts are only extended to "a failed organisation". Without mincing his words, he 
had also noted that the company was in a precarious condition as far as the assumption of a going concern (an entity ordinarily viewed as continuing in business for the foreseeable future) was concerned. He wrote:

... about "going concern", the fundamental principle upon which financial statements are prepared. With the next financial year end March 2015 only two weeks away, I fail to see how 1MDB's external auditors Deloitte can continue to rely on the appropriateness of this assumption without an explicit guarantee by the company's shareholders, the MOF, that it will meet the company's financial obligations.

In his view, the 1MDB was no longer to be considered a "going concern" without financial support from the government. He claimed that for the auditor Deloitte to sign off the accounts of the company on a going concern basis, it would need a letter from the shareholders, MOF, stating its explicit commitment to provide the necessary financial support to 1MDB. The failure of getting such letter, he pointed out, would mean that the 1MDB's financial statements had to be prepared on a non-going concern or "break-up" basis.

Now, do you agree with A.H. Manaf's stance above on the issue of going concern as far as the $1 \mathrm{MDB}$ was concerned by the third quarter of 2015 which was supposed to coincide with the publication of its 2015 financial statements? What would your stance be like as far as the going concern assumption for the company in late 2014 was concerned when its financial statements for 2014 had just come out? In other words, do you believe that 1MDB was still a going concern by the time its 2014 financial statements came out in the last quarter of 2014 ?

\section{References}

Anand, R. (2015a, March 15). 1MDB has hit raw nerve, converts BN backers'. Malaysiakini. Retrieved from https://www.malaysiakini.com/news/292090

Anand, R. (2015b, May 23). Minister may face rights panel on 1MDB loan. Malaysiakini. Retrieved from https://www.malaysiakini.com/news/293277

Ask 1MDB to 'clear the air' before PAC, DAP tells Ahmad Maslan (2014, December 19). The Malaysian Insider. Retrieved from http://www.themalaysianinsider.com/malaysia/article/ask-1mdb-to-clear-the-air-before-pac-d ap-tells-ahmad-maslan

Bernama (2014, November 17). Investments professionally managed, says 1MDB. Kinibiz. Retrieved from http://www.kinibiz.com/story/corporate/121880/investments-professionally-managed-says-1 mdb.html?utm_source=applet_mkinicom\&utm_medium=web\&utm_campaign=mkinicom

Come clean on 1MDB RM2bil due, gov't told (2015, February 6). Malaysiakini. Retrieved from https://www.malaysiakini.com/news/288500

Diyana, I. (2014, November 10). 1MDB terus rugi, tidak mustahil akan muflis, kata PKR. The Malaysian Insider. Retrieved from 
http://www.themalaysianinsider.com/bahasa/article/1mdb-terus-rugi-tidak-mustahil-akan-muf lis-kata-pkr

FMT Reporters (2015a, February 13). Ananda believed to have rescued 1MDB from default. Free Malaysia Today. Retrieved from http://www.freemalaysiatoday.com/category/nation/2015/02/13/ananda-believed-to-have-resc ued-1mdb-from-brink-of-default/

FMT Reporters (2015b, March 25). 1MDB settled: Was it Cayman, Ananda, or private investors? $\quad$ Free Malaysia Today. Retrieved from http://www.freemalaysiatoday.com/category/nation/2015/03/25/1 mdb-settled-was-it-caymanananda-or-private-investors/

FMT Reporters (2015c, March 26). Critic accuses 1MDB's Arul of lying. Free Malaysia Today. Retrieved from http://www.freemalaysiatoday.com/category/nation/2015/03/26/critic-accuses-1mdbs-arul-oflying/

FMT Reporters (2015d, March 16). Land rationalisation, IPO to deliver 1MBD from its quagmire. Free Malaysia Today. Retrieved from http://www.freemalaysiatoday.com/category/nation/2015/03/15/land-rationalisation-ipo-to-de liver-1mbd-from-its-quagmire/

FMT Reporters (2015e, March 16). Pua: Govt continues to downplay severity of 1MDB's troubles. Free Malaysia Today. Retrieved from http://www.freemalaysiatoday.com/category/nation/2015/03/16/pua-govt-continues-to-downp lay-severity-of-1mdbs-troubles/

Gabriel, A. (2015, March 11). Putrajaya extends nearly RM1 bln loan to 1MDB a fortnight ago - S'pore BT. Retrieved March 15, 2015, from http://www.theedgemarkets.com/my/article/putrajaya-extends-nearly-rm1-bln-loan-1mdb-fort night-ago-spore-bt

Gunasegaram, P. (2013, April 24). 1MDB revisited: A new enigmatic name emerges - SRC. Kinibiz. $\quad$ Retrieved from http://www.kinibiz.com/story/issues/16932/1mdb-revisited-a-new-enigmatic-name-emerges-s rc.html

Gunasegaram, P. (2015, April 29). 10 things 1MDB should disclose. Malaysiakini. Retrieved from https://www.malaysiakini.com/columns/296794

Jacob, S. (2014, April 22). 1MDB: Auditors highlight critical areas for accounts. Kinibiz. Retrieved from http://www.kinibiz.com/story/issues/82559/1mdb-auditors-highlight-critical-areas-for-accoun ts.html

Khairie, H. (2015a, March 16). 'Daim cautioned Najib over 1MDB'. Kinibiz. Retrieved from http://www.kinibiz.com/story/corporate/154012/\%E2\%80\%9Cdaim-cautioned-najib-over-1m 
$\mathrm{db} \% \mathrm{E} 2 \% 80 \% 9 \mathrm{D} . \mathrm{html}$ ?utm_source=applet_mkinicom\&utm_medium=web\&utm_campaign= mkinicom

Khairie, H. (2015b, April 4). 1MDB, come clean to all Malaysians. Kinibiz. Retrieved from http://www.kinibiz.com/story/exclusive/158399/1 mdb-come-clean-to-all-malaysians.html

Khairie, H. (2015c, April 13). If 1MDB were public listed... Kinibiz. Retrieved from http://www.kinibiz.com/story/tigertalk/160113/if-1mdb-was-public-listed\%E2\%80\%A6.html ?utm_source=applet_mkinicom\&utm_medium=web\&utm_campaign=mkinicom

Khairie, H. (2014a, December 19). For 1MDB, half-truths can't mask numbers. Kinibiz. Retrieved

from http://www.kinibiz.com/story/tigertalk/129491/for-1mdb-half-truths-can\%E2\%80\%99t-masknumbers.html

Khairie, H. (2014b, April 22). 1MDB: RM2.7 bil in paper revaluation gains. Kinibiz. Retrieved from http://www.kinibiz.com/story/issues/82526/1 mdb-rm2.7-bil-in-paper-revaluation-gains.html Khairul, K. (2015, February 17). Did Putrajaya bail out 1MDB? Kinibiz. Retrieved from http://www.kinibiz.com/story/corporate/145931/did-putrajaya-bail-out-1mdb.html

Malaysiakini (2015, March 25). 'Ananda's firm helped secure RM2 bil 1MDB refinancing'. Kinibiz. Retrieved from http://www.kinibiz.com/story/corporate/156315/anandas-firm-helps-securing-rm2-bil-1mdb-r efinancing.html?utm_source=newsletter1\&utm_medium=email\&utm_campaign=kinibiz-new sletter

Mohd-Izwan (2015, April 17). Minister admits 1MDB debt burdensome. The Malaysian Insider. Retrieved from http://www.themalaysianinsider.com/malaysia/article/minister-admits-1mdb-debt-burdensom e-putrajaya-to-stop-all-new-loans

Mustafa, M. (2015, April 27). DAP won't let up on 1MDB, says Guan Eng. The Malaysian Insider. $\quad$ Retrieved from http://www.themalaysianinsider.com/malaysia/article/dap-wont-let-up-on-1mdb-says-guan-en $\mathrm{g}$

$\mathrm{Ng}$, E. (2014, November 17). 1MDB abusing proceeds from US\$3 billion bond, says DAP lawmaker. The Malaysian Insider. Retrieved from http://www.themalaysianinsider.com/malaysia/article/1mdb-abusing-proceeds-from-us3-billio n-bond-says-dap-lawmaker

1MDB will haunt capital markets, drive down ringgit, says DAP (2015, March 15). The Malaysian Insider. Retrieved from http://www.themalaysianinsider.com/malaysia/article/1mdb-will-haunt-capital-markets-drivedown-ringgit-says-dap 
1MDB in financial distress - A.H. Manaf (2015, March 17). The Malaysian Insider. Retrieved from http://www.themalaysianinsider.com/sideviews/article/1mdb-in-financial-distress-a.h.-manaf

'1MDB got loan extension from Bank Negara' (2014, December 13). Malaysiakini. Retrieved from https://www.malaysiakini.com/news/283377

Pua, T. (2014, November 24). Ahmad, don't make 1MDB promise you can't keep. Malaysiakini. Retrieved from https://www.malaysiakini.com/news/281373

Pua, T. (2015, February 8). 1MDB keeps funds abroad when debts overdue? Malaysiakini. Retrieved from https://www.malaysiakini.com/news/288633

Sharmila, G. (2015, February 13). Halt the silence, 1MDB. Kinibiz. Retrieved from http://www.kinibiz.com/story/tigertalk/145127/halt-the-silence-1 mdb.html?utm_source=appl et_mkinicom\&utm_medium=web\&utm_campaign=mkinicom

Zachariah, E. (2014, November 11). DAP rep, in diatribe, says 1MDB risks defaulting RM42 billion loan. The Malaysian Insider. Retrieved from http://www.themalaysianinsider.com/malaysia/article/dap-rep-in-diatribe-says-1mdb-at-risk-o f-defaulting-on-unpaid-loans 